COMET

A Photographic Installation

by Gregory Severin

A MRP presented to Ryerson University in partial fulfillment of the requirements for the degree of Master of Fine Arts in the program of Documentary Media (MFA)

Toronto, Ontario, Canada, August 2019

(C) Gregory Severin, August 2019 


\author{
AUTHOR'S DECLARATION FOR ELECTRONIC SUBMISSION OF A MRP \\ I hereby declare that I am the sole author of this MRP. This is a true copy of the MRP, including \\ any required final revisions. \\ I authorize Ryerson University to lend this MRP to other institutions or individuals for the \\ purpose of scholarly research. \\ I further authorize Ryerson University to reproduce this MRP by photocopying or by other \\ means, in total or in part, at the request of other institutions or individuals for the purpose of \\ scholarly research. \\ I understand that my MRP may be made electronically available to the public.
}




\begin{abstract}
COMET
MFA, Documentary Media, 2019

Gregory Severin

Yeates School of Graduate Studies

Ryerson University
\end{abstract}

ABSTRACT

This major research paper is written to accompany the photographic installation COMET. The project examines the town of Raymond, Alberta and their high school football team, the Raymond Comets. I look to visualize the specific reality of Raymond, especially their approach to sports and how it interfaces with their faith as members of the Church of Jesus Christ of Latter-day Saints. This paper supports COMET in three main ways. I examine my own history of sport and my relationship to the Raymond Comets, I overview their faith and its relationship to sport, and I provide my own history developing COMET. I detail the theoretical and practical approaches used to produce COMET, examining the role of observation within photography, and describing the process of building the narrative within the gallery. Finally, I describe influences on COMET, and detail how and where COMET fits in the history of the documentary tradition. 


\section{TABLE OF CONTENTS}

List of Appendices $\quad$ V

$\begin{array}{ll}\text { Introduction } & 1\end{array}$

$\begin{array}{ll}\text { Project Description } & 2\end{array}$

$\begin{array}{ll}\text { Methodology } & 11\end{array}$

$\begin{array}{ll}\text { Relevance } & 21\end{array}$

$\begin{array}{ll}\text { Conclusion } & 26\end{array}$

$\begin{array}{lr}\text { Appendix } 1 & 28\end{array}$

$\begin{array}{ll}\text { Appendix } 2 & 30\end{array}$

$\begin{array}{ll}\text { Bibliography } & 36\end{array}$ 


\section{LIST OF APPENDECIES}

$\begin{array}{lr}\text { APPENDIX } 1 & 28\end{array}$

$\begin{array}{ll}\text { Installation Progress Diagram } & 28\end{array}$

$\begin{array}{ll}\text { Didactic Wall Piece } & 29\end{array}$

$\begin{array}{ll}\text { APPENDIX } 2 & 30\end{array}$

Figure 1: After a Loss $\quad 30$

Figure 2: Before Dinner $\quad 31$

Figure 3: Brady's Jacket $\quad 32$

Figure 4: Warm-up $\quad 32$

Figure 5: Seminary Class 33

Figure 6: Team Bus 33

Figure 7: Dinner Prayer 34

Figure 8: Pre-game $\quad 35$ 


\section{INTRODUCTION}

COMET is a photographic documentary project that attempts to display the reality of the Raymond Comets, through visualizing the religious and social realities that exist at a community scale. The project consists of 22 prints on the wall of the gallery, ${ }^{1}$ with the images being sourced from three separate trips to the town of Raymond, Alberta. The majority of these photographs are what I would describe as "non-sport" images. These are images that feature sport in their surface content, and utilize this theme to inform the larger nature of Raymond's community. These images are key in exemplifying the importance of sports, and the needs they meet from a functionally religious standpoint. The Church of Jesus Christ of Latter-day Saints (LDS) is a defining presence in the town of Raymond. The tenets of their faith shape Comet Football into the unique program it is. In this paper, I argue that for the LDS faith in general, sport is a liturgical act. During the production of this project, I had to come to terms with this reality, changing my methodology and considering my position within Raymond as a photographer. Upon the completion of this project, I have come to see COMET occupying a space within the documentary tradition that adapts both new and old forms of photojournalism and observational photography, in order to relay a larger narrative. COMET works to convey the reality of Raymond, by utilizing images that visualize their unique specific combination of faith, culture, and sport.

\footnotetext{
${ }^{1}$ COMET. Gallery IX, Toronto, Ontario. June 14, 2019
} 


\section{PROJECT DESCRIPTION}

The Comets are a high school football team from Raymond, Alberta, a town south of Lethbridge. They have an excellent and consistent team, having won seven tier-1 Alberta provincial championships. Raymond and its high school have a tiny population, but they compete against schools that have thousands of students. ${ }^{2}$ I first became aware of the Comets when I was around fourteen years old, playing community football in Edmonton, Alberta. There were rumblings about a team from a small town near the Montana border, who are Mormon and amazing at football. The legend of Raymond football stayed with me throughout high school, and when I got to witness them play in my senior year I was not expecting the level of skill they displayed. They were faster and smarter than any other youth teams I had ever seen. The next time I came across the Raymond Comets was when I began to play varsity football at the University of Alberta. The players who were from Raymond were still standouts. During my tenure with the $\mathrm{U}$ of A Golden Bears, it was clear that players from Raymond had an elevated intelligence and athleticism for the game. Even at the university level, they were consistently faster and tougher than average. In my rookie season, I was placed on the starting roster and shared Rookie of the Year honours with my friend Connor Ralph, who is from Raymond and was my main point of contact for this project. The year before I joined the University of Alberta Golden Bears, my teammates who were from Raymond had played on a team where they were ranked as the best high school team in the country. ${ }^{3}$ It is hard to emphasize how difficult it is to be excellent at football. The consistent performance of these players who I began to know personally led me to ask the question, "Why are they so good?" This question fuelled my desire to do the COMET project and shed more light on their reality.

To understand this project in more depth, it was necessary for me to become more familiar with the relationship between sport and religion, as well as the more specific relationship between sport and the faith of the Church of Jesus Christ and Latter-day Saints (LDS). It was also crucial to develop a knowledge of Raymond's foundation, in order to provide a starting point for the beginnings of their sporting history. During 1872, in an effort to promote

\footnotetext{
${ }^{2}$ Cosh, Colby. "A Prairie Football Phenomenon." Macleans.ca. November 02, 2011. https://www.macleans.ca/news/canada/friday-night-lightson-the-prairie/.

3 "\#CFC50 National High School Rankings (Champions \& Runner-Up)." CanadaFootballChat.com. https://canadafootballchat.com/cfc-top-50national-high-school-rankings-champions-runner-up/.
} 
expansion and development of western Canada, the Canadian federal government was offering 160 acres of land to anyone over the age of 21 , who could pay a $\$ 10 \mathrm{fee}$, with a required "...cultivation of 40 acres and build a dwelling within three years." time, John Taylor, sent Charles Ora Card to survey and establish LDS settlements. Card eventually established Cardston, which still stands today, and is the land upon which the Southern Alberta Mormon Temple sits, also known as the "Alberta Stake of Zion." Hearing about the "entrepreneurial potential" in Southern Alberta, Jesse Knight eventually purchases close to 285,400 acres of land cumulatively after sending his sons Oscar Raymond (whom the town of Raymond is named after) and John Williams to survey the land in $1901 .^{6}$ The owner of the land, (and much of Southern Alberta) Sir Alexander Galt, began selling portions of his land to private citizens, after the interest of large companies waned. As a provision of the agreement for the purchasing of large swaths of land, there was a requirement that there was to be a sugar factory: "On August 11, 1901, Apostle John W. Taylor, Jesse Knight, and other Church of Jesus Christ leaders selected the location of the sugar factory and townsite."7

The Mormon ethic was built into the very land that was purchased, and the LDS Church is still understood as the "overarching meta theme" of Raymond's history. ${ }^{8}$ The town's establishment of organized sports began with funding the Raymond Amateur Athletic Association (RAAA) in 1924 and this signals the beginning of a sport centric attitude that would go on to influence their culture regarding sport for years to come. ${ }^{9}$ The foundation of an association like this one provides an actual understanding of sport in the LDS context, and how it is used as a method for the Mormon church to implement and teach elements of sport that overlap with faith. Sport brought the community of youth together, and the foundation that had been set almost 100 years ago shows its influence today. Whether it was between Raymond and the neighbouring towns of Cardston or Stirling, there is no doubt that these rivalries found their footing in the original implementation of sport and community through the RAAA. It also took around 3 years for hockey to be brought to Raymond, with the first game being organized in

\footnotetext{
4 "History of Raymond." Town of Raymond. https://raymond.ca/history-of-raymond/\#history. https://raymond.ca/wpcontent/uploads/2019/04/RaymondHistoricContext14Oct31Lo-res_33f3f697a3.pdf

5 "History of Raymond." Town of Raymond. https://raymond.ca/history-of-raymond/\#history. https://raymond.ca/wpcontent/uploads/2019/04/RaymondHistoricContext14Oct31Lo-res_33f3f697a3.pdf 15

${ }^{6}$ Ibid. 15.

${ }^{7}$ Ibid

${ }^{8}$ Ibid. 12.

${ }^{9}$ Ibid. 44.
} 
1927. ${ }^{10}$ Originally, baseball and basketball were amongst the initial sports played. The sports that are present at the time of inception are the sports associated most strongly with the LDS faith, in their accessibility and ease of use. The baseball games were played at whichever fields were available, and basketball courts were incorporated into LDS churches: “...The unique accommodation of gymnasiums in Church of Jesus Christ churches, ensured ample courts for practice and tournaments." 11 Such sports, even at the inception of their town, allude to the manner in which their beliefs are transplanted into new territory through sport, itself being a liturgical act as well as a missionary apparatus through which to grow their faith, and will be discussed further below.

A brief history of the Mormon Church is essential to clarify their type of faith. There are two major moments that contribute to the creation and origin of the LDS Church. First, Mormonism was founded by Joseph Smith in 1830. When he did not know where to turn in his faith, due to the "...conflicting claims of the various faiths", he "ask[ed] of God" for himself: ${ }^{12}$

"In a wooded grove near the family farm, Joseph knelt to pray. There in that secluded place, in the most dramatic revelation since biblical times, God and his Son, Jesus Christ, appeared to the boy and gave him instructions. He was commanded to join none of the existing churches and was told that God would restore to earth the Church originally organized by Jesus Christ, with all of its truths and priesthood authority. Ten years later, after a series of revelations and dramatic visitations to Joseph and others, The Church of Jesus Christ of Latterday Saints was officially organized on 6 April 1830, in Fayette, New York.",13

Before the institution of the LDS church in 1830, there was the secondary major occurrence of what could be considered foundational to the Mormon faith:

"In September of 1823, Joseph experienced a visitation from an ancient prophet, a man who had lived and died in the Western Hemisphere centuries earlier. This resurrected man, whose name was Moroni, directed Joseph to a hill near Palmyra, where he showed him a religious history of an ancient American civilization engraved on metal plates and buried in the ground. Four years later, Joseph was permitted to take the record and translate it. The Book of Mormon, named for one of the ancient American prophets who had compiled it, was first published in 1830.

\footnotetext{
${ }^{10}$ Ibid.

${ }^{11}$ Ibid.

12 "History of The Church of Jesus Christ of Latter-Day Saints." newsroom.churchofjesuschrist.org, August 1, 2016.

https://newsroom.churchofjesuschrist.org/article/history-of-the-church-of-jesus-christ-of-latter-day-saints.

${ }^{13}$ Ibid.
} 
The Book of Mormon contains religious writings of civilizations in ancient America between about 2200 B.C. and A.D. 421. It includes an eyewitness account of the ministry of Jesus Christ on the American continent following His resurrection in Jerusalem." 14

Joseph Smith died in 1844, after being shot by a mob in Carthage, Illinois. ${ }^{15}$ During that year, some former Mormons reported that Joseph Smith was polygamous, and sought to publish this information. ${ }^{16}$ In an effort to stop the release of this news, Smith had the printing presses of the Navuoo Explositor destroyed, being charged afterwards for inciting riot. ${ }^{17}$ Smith was then charged and imprisoned for treason after declaring a martial law in Navuoo, Illinois (where he was mayor), and was killed before he could stand trial. ${ }^{18}$ According to reports and LDS documents, he was estimated to have between 30 to 40 wives, the oldest being 56 and the youngest being $14 .^{19}$

In terms of understanding the LDS faith in relationship to sport, the work of scholars based out of Brigham Young University proved quite instrumental. Research regarding the phenomenon of what is termed "Muscular Mormonism" was indispensable for providing the necessary understanding of both the history of sport and Mormonism, and their interaction and reaction with one another. This movement brings to the forefront the importance of physical and spiritual health, as directly tied to the nature of the soul. ${ }^{20}$ Richard Kimball, associate professor at Mormon-owned Brigham Young University in Provo, Utah, proposes that the current iteration of Muscular Mormonism is an offshoot of "Muscular Christianity," itself defined by "a shift in religious thinking that transformed the physical body from a spiritual liability into an instrument for positive spiritual and social good." ${ }^{21}$ Kimball very importantly situates the primacy of the mind and body relationship as a foundational interplay, with the prophet Joseph Smith existing

\footnotetext{
14 "History of The Church of Jesus Christ of Latter-Day Saints." newsroom.churchofjesuschrist.org, August 1, 2016.

https://newsroom.churchofjesuschrist.org/article/history-of-the-church-of-jesus-christ-of-latter-day-saints .

${ }^{15}$ Ibid.

${ }^{16}$ Fletcher Stack, Peggy. Religion News Service. "Book Examines Pivotal Moment in US History: Joseph Smith's Murder.” The Washington Post. WP Company, July 2, 2014. https://www.washingtonpost.com/national/religion/book-examines-pivotal-moment-in-us-history-josephsmiths-murder/2014/07/02/981ab6b4-0231-11e4-8bb2-6b921949ecfa story.html.

17 "Joseph Smith: The Murder of the Mormon Prophet and Subsequent Trial." Illinois History Lincoln Collections, October 11, 2018. Accessed September 2019. https://publish.illinois.edu/ihlc-blog/2018/10/11/joseph-smith-the-murder-of-the-mormon-prophet-and-subsequent-trial/. ${ }^{18}$ Ibid.

${ }^{19}$ Goodstein, Laurie. "It's Official: Mormon Founder Had Up to 40 Wives.” The New York Times. The New York Times, November $11,2014$. Accessed September 2019. https:/www.nytimes.com/2014/11/11/us/its-official-mormon-founder-had-up-to-40-wives.html. ; "Plural Marriage in Kirtland and Nauvoo." The Church of Jesus Christ of Latter-day Saints. Accessed September 2019.

https:/www.churchofjesuschrist.org/topics/plural-marriage-in-kirtland-and-nauvoo?lang=eng.

${ }^{20}$ Kimball, Richard. "Muscular Mormonism." The International Journal of the History of Sport 25, no. 5 (2008): 549-578.

${ }^{21}$ Ibid. 549.
} 
as both a spiritual and physical role model, ${ }^{22}$ and Smith himself defining the very soul of man as the "spirit and the body." ${ }^{, 3}$ Smith embodies the type of Muscular Mormonism, being "[a] mix of Adonis, Jesus and Frank Merriwell., ${ }^{24}$ For reference, Frank Merriwell was a staple of American youth sport fiction, a character who was the creation of writer Gilbert Patten. Merriwell's stories were defined by athletic success and "sterling virtue. ${ }^{25}$ These became the template roadmap for Muscular Christians, and later, Muscular Mormons. The LDS church has also specific physical guidelines, such as The Word of Wisdom. A section within the Book of Mormon, The Word of Wisdom contains the food and drink "rules" -teachings claimed to be given to Joseph Smiththat dictate specific dietary requirements, such as no-caffeine, no-alcohol, and no "hot drinks." The importance of the physical body, amongst the myriad of other theological tenets that are included in the LDS religious canon, has created a specific and repeated occurrence in sports across time. Part of the LDS sport experience is the maximization and utilization of the intrinsic ethical and character-building aspects of sport, and the application of these merits and lessons into their religious life. This exists as a counter to the contemporary sport-religion interaction, defined by the grafting of sport onto a religious framework, where success in sport becomes a quasi-religious goal. The most typical example of this is Texan football culture, in that it moves the end goal -winning the game- into the ultimate position. Describing high school football in Texas, Justin J. Hefley writes: "the game has become more competitive, lucrative, and the focus has shifted to achievement and winning, as students who played football for 13,000 schools strived to receive a college football scholarship. ${ }^{, 27}$ The sporting goal becomes effectively overvalued, and the stakes that are placed on players to win, including at the high school level are too high for their own good. The act of victory or success becomes entangled with life itself. The importance here, and the necessary distinction that makes a religious community such as Raymond perfect for examining the religion-sport relationship, is that sport has become a means of acting out religious concepts, fulfilling teachings and goals that are inherent in the LDS faith. Some of the fundamental aspects of Mormon manhood are: "intellect... developed and

\footnotetext{
${ }^{22}$ Ibid. 554.

${ }^{23}$ Ibid. 550 .

${ }^{24}$ Ibid. 554.

${ }^{25}$ Kimball, Richard. "Muscular Mormonism." The International Journal of the History of Sport 25, no. 5 (2008): 558.

${ }^{26}$ Ibid. 556.

${ }^{27}$ Hefley, Justin J. "Perceptions of Texas High School Football Coaches regarding Concussions." Order No. 10268622, Concordia University

(Oregon), 2017. http://ezproxy.lib.ryerson.ca/login?url=https://search-proquest-

com.ezproxy.lib.ryerson.ca/docview/2201904593?accountid=13631. 47.
} 
maintained physical powers ... moral and spiritual life ... faith and courage." ${ }^{28}$ Through the building of external and internal toughness that sport requires, these religious goals for young men in the Mormon Church are simultaneously achieved in a literal manner. As COMET is a project addressing an all-male sports team, examining the impact of the tradition of Mormon manhood is largely unavoidable, and important in framing their current reality. However, many of the theological ideas discussed here are no longer strictly gendered. I would argue many of these formerly exclusive masculine concepts now apply to Women's sports, as evidenced by the dominant performance of Comets women's Rugby, having won ten out of the last eleven provincial championships (as of 2019). This is why, in no uncertain terms, sport means more in the LDS faith compared to even the mainstream Christian tradition. Here the understanding of the body in the Christian tradition is tied to the core acts of Christ and His sacrifice, and while those successfully scale to emphasize the value and importance of taking care of one's body, sport does not become liturgical. In the LDS tradition, sport moves into the liturgical space. It is a publicly observable ritual or action, done with the benefit of fulfilling religious or theological principles or teachings, in order to have the chance of being rewarded the potential value of their observance: a closer relationship to their faith.

At the core of the LDS sporting ethic is the importance of the sporting act moving outside of the self. There is a common phrase within football that you have to play for the guy beside you. Another is, "Do Your Job." These messages seem to be antithetical, but the emphasis on doing one's job is the adoption of full responsibility, or control of the self, something that is so definite and clear within the LDS tradition. It is a defining quality of Mormon manhood, as the emphasis in Mormon teaching is the goal of gaining success in both "God and Man's world."29 In the research regarding LDS communities and mental health, the idea of personal control is made out to be both a major aspect of the LDS faith. Practising control of "industriousness, the careful use of time, restraint of aggression, control of temper and sexual impulses, and compulsive performance of religious and personal duties", both render model members of the church, but it has also been suggested that such behaviour can potentially become pathological,

\footnotetext{
${ }^{28}$ Roberts, B.H. 'Sphere of YMMIA Activities', 202. quoted in Kimball, Richard. "Muscular Mormonism." The International Journal of the History of Sport 25, no. 5 (2008): 561.

${ }^{29}$ Sumerau, J. E., Ryan T. Cragun, and Trina Smith. "'Men Never Cry": Teaching Mormon Manhood in the Church of Jesus Christ of Latter-Day Saints." Sociological Focus 50, no. 3 (2017): 218.
} 
and could lead to obsessive compulsive disorder. ${ }^{30}$ These areas of self-control and precise responsibility overlap well with the factors that are required for any sort of success in sport. Part of their anxiety has to do with the belief that the answers have already been given through their sacred texts. ${ }^{31}$ So the expectation of perfection can be daunting, and even anxiety inducing, especially when there is no room for human error: "Mormons typically feel that they are totally responsible for all their actions and feelings - an attitude which when taken to extremes can results in despair, depression, and inaction bordering on paralysis. ${ }^{, 32}$ The adoption of responsibility is not only a keystone to the lives of its members, but it is also because there is no reason not to. "Do your job" could be concluded with "so the person beside you does not have to."

Sport also acts to form narratives of guidance and inspiration within the Church of Jesus Christ of Latter-day Saints. The essence of what could be called "narrativization" in religion, which is essentially how principles and teachings are conveyed through a narrative structure, are found in the mainstream Christian tradition with the Letters of the Apostles and the Lives of the Saints. The main idea of transformation in the LDS faith is the movement from the state of "God-in-Embryo" to God, as members of the LDS church believe that they are the same race as God himself. ${ }^{33}$ Namely, there is no room for a type of growth that is narratively and connectively unique, that sits directly within a church structure. Sports narratives can fill the role of earthly transformation. The creation of narratives of accomplishment, of the Mormon ethic being fully lived out, can be historically defined through the athletic accomplishments and feats of both narrative and real-world characters. Steve Young, all-pro NFL quarterback and genuine celebrity of the San Francisco 49ers during the 1980's was a major figure in the LDS Community. As a member of the LDS church that played football on Sundays, he was also watched by many practising members of the LDS church. This lack of obligation was humorously dubbed the "so-called Steve Young exemption." 34 The LDS rule of abstaining from sport on Sundays was lifted, by both Young and his fans, who viewed his play as an inspirational figure to be seen as emblematic of what a Mormon athlete can accomplish, and the value of their

\footnotetext{
${ }^{30}$ Lyon, S.J. "Psychotherapy and the Mormon Faith". J Relig Health (2013) 52: 622-630. 624. https://doi.org/10.1007/s10943-013-9677-2 ${ }^{31}$ Ibid. 626.

${ }^{32}$ Koltko, M. E. (1991). The psychological foundations of the Mormon client in counseling and psycho-therapy. Journal of the Association of Mormon Counselors and Psychotherapists, 17(1), 1-26.

${ }^{33}$ Lyon, S.J. "Psychotherapy and the Mormon Faith". J Relig Health (2013) 52: 622-630. 624. https://doi.org/10.1007/s10943-013-9677-2

${ }^{34}$ Kimball, Richard. "Muscular Mormonism." The International Journal of the History of Sport 25, no. 5 (2008): 572
} 
teachings. ${ }^{35}$ After all, Young wasn't merely successful, but in reality, he was a true all-star and Superbowl champion. ${ }^{36}$ Young's story is also an example of how the narrative of success, particularly in sports, can override the theological tenets of the LDS faith.

Another example of how the narrative of success overrides the theological tenets of the LDS faith occurs in Paul Dunn. The accounts and narratives shared by Dunn, a higher-up member of the Mormon church who himself told stories of his great and prestigious military and athletic accomplishments, were positioned well within the LDS ethic and could be captivating for his audiences. ${ }^{37}$ Dunn had a high-ranking role within the LDS Church, ${ }^{38}$ and stepped down when The Arizona Republic, working from investigations by Lynn Packer, broke the news in 1991 that parts of Dunn's narratives had been falsified. ${ }^{39}$ When this was found out, some members of the LDS Church met Dunn's actions with disdain, while others still supported his narratives. According to one supporter, his stories kept youth close to the Church during the “...60s and 70s, when everything good and moral was being challenged, [Dunn] was able to reach the youth of the Church of Jesus Christ of Latter-day Saints and help them hang on to what was good like very few others." "40 According to Kimball, the Church-owned Deseret News, even published parts of his untrue biography in his obituary, ${ }^{41}$ and Dunn's “... supporters seemed to accept [his] argument that the end of teaching important principles was more important than the means of truthful story telling. $" 42$ The narrative, the guide to maximize potential, is placed higher than the truth, in that value is given to the story and its potential function whether it happened or not. But the reality is that success is a sort of sporting currency. Whether it's by Steve Young of the San Francisco 49ers, or Raymond's own Comets, it holds true even outside of their own faith. It acts as a non-fiction counterpart to these narratives, the one that is recognized by believers and non-believers alike, and that value is hard to deny. The structural reliance on sport, both theologically and liturgically, is an essential part of the LDS faith that gives credence to sport having more meaning in their communities- The harder these players play, the better they

\footnotetext{
${ }^{35}$ Ibid. 571.

${ }^{36}$ Ibid. 572.

${ }^{37}$ Kimball, Richard. "Muscular Mormonism." The International Journal of the History of Sport 25, no. 5 (2008): 568

${ }^{38}$ Ibid. 561

${ }^{39}$ Ibid. 577.

${ }^{40}$ Ibid. 570 .

${ }^{41}$ Ibid.

42 Ibid. 571.
} 
are as members of the Church. As sport elevates the individual through struggle, the collaborative nature of religion also assists in their understanding of a team concept.

Raymond's success has to do with that combination of place, faith, and community, all three working as influential factors in making these players great. In high school, there is no way to truly "recruit" athletes, as there is in university sport. You cannot bring players in from halfway across the country in order to help improve the quality of your team. The reality of the consistency in Raymond's play is a marker of their belief in the value of sports from a social and religious perspective. There are all levels of Comet football, from elementary school children to high school. And many kids on the current high school team have played at all these levels. This is even better than recruiting; having generational players worked through the system, until they get to the high school level. This includes having parents who played for the Comets, including Brady Baines' whose father was one of my contacts for this project and is also a coach on the team. This generational approach explains their heightened game intelligence and ball sense, and their willingness to "run through a wall" (a common football colloquialism). This generational element to Comets football shows the reality of sports as a "mini-life", a term picked up from Raymond seminary teacher Dan Bikman. The term "mini-life" describes how sport provides access to essential parts of the human experience within the framework of athletic competition. Feeling suffering and pain, joy and sadness, success and failure (and learning how to control these outcomes) at a young age, and outside of the stakes of life, is how sports acts as a "minilife." Hearing this from someone who is tuned into the fabric of society in Raymond, was one of the defining moments for my understanding of this project. Using this knowledge, I believe my approach to this project is unique. And although football has been famously captured in documentary photographs as part of larger football narratives, such as Robert Clarks's photographs in H.G. Bissinger's "Friday Night Lights", 43 I argue COMET approaches it from a different angle. This project looks to replace the "Why?" with "How?", exploring how this team is an embodied manifestation of the concept of sport as life

\footnotetext{
${ }^{43}$ H. G. Bissinger, Friday Night Lights: A Town, a Team, and a Dream. Da Capo, 2015.
} 


\section{METHODOLOGY}

Within the Methodology section of this paper, I will primarily divide my expectation of what Raymond was going to be, from the reality I observed on the ground. This separation is crucial in framing the process of documenting Raymond and the Comets. Using specific examples, I will break down the key concepts and influences that have shaped my approach to working in Raymond, as well as the necessary adjustments and changes that occurred in order to effectively produce COMET.

Expectations of openness defined my method for the first portion of my project. There was a certain setting I held in my mind as to how Raymond was going to exist visually. I expected the original three pillars of my project, Faith, Community, and Football to be lived out very clearly and publicly: a large population of the town are members of the LDS Church, and the town has a strong legacy of success in high school sports. The distinction I did not make at the time was between understanding what I wanted to produce visually, versus attempting to plan an entire project in the first year of the program without actually being present. Pre-presence, the approach to the project should have been more like a set of parameters than any actual expectations as to how the work will look. This was determined through my finding that access has layers, and the main apparatus to achieve this is the building of relationships with both the subjects and the environment.

I learned that building relationships is not simply being allowed to shoot photos of someone, but is instead the driving force behind access itself. It begins with the knowledge gained from presence: nothing can replace this, regardless of what kind or manner of preparation one does. Once presence activates preparation and makes it functional within the space, gaining familiarity is the apparatus that builds the relationship. Becoming familiar with where you are, the people you meet, how people act, and understanding how people exist visually, are the specifics of this process. Presence is a reciprocal procedure, as it creates the reality of both seeing and being seen, both informing what you learn about where and whom you interact with, as well as giving them an opportunity to know you, as a documentarian. Operating consistently is also a necessity. This is pragmatic, as the documentarian is in a space that is not their own. 
However, it also is important that one presents themselves in a manner that does service to the reality of the space, and to not flavour the approach and the work in a way that is self-serving, an unfortunate option laid out by documentary theorist James Linton. ${ }^{44}$ Linton's influence on my process relates to his considerations of responsibility as a documentarian, and more specifically his recognition of the deductive and inductive nature of a work: between how I present work to an audience in my subjective state, and how the work is interpreted by them, outside of my control. $^{45}$ To illustrate, Linton includes a quote from Bill Nichols: "Some sort of trade-off has to be effected between presenting a point of view, and allowing one's subjects to "speak for themselves" and one's audience the freedom to come to their own conclusions." ${ }^{46}$ My answer is to come to terms with my position as a photographer, and to properly implement the shape of the visual narrative through sequence (the latter of which I will outline later in this section). Regarding my position as photographer, Linda Alcoff's ideas are necessary to consider. Her concept that one's position either legitimizes or delegitimizes what one may say, and that those in privileged positions speaking for the less privileged can encourage oppression ${ }^{47}$ may apply to documentary, but this type of language reinforces an oversimplified approach to the documentarian-subject relationship. To consider the subject either above or below the documentarian strips them of any ability or agency to change or interact with the process or outcome of the documentary. The privileged/not privileged belief exists solely to the benefit of the one considered "above" the other. When applied to documentary, this type of language overvalues the documentarian and completely robs the subject of any ability to be understood as having agency. The documentarian-subject (or privileged/not privileged, in Alcoff's terms) must move to a properly considered lateral position, where neither is placed "above" or "below" the other. Putting oneself in an open and physical position to see as clearly as possible, acknowledging the subjective specifics of my position, and being ready to photograph, is perhaps the most important pragmatic element of my methodology. And the reality of access in Raymond was that people only showed what they want to show, thereby exercising their agency as subjects, and altering my approach and understanding of this project and community during the production of COMET.

\footnotetext{
${ }^{44}$ Linton, James M. "The Moral Dimension in Documentary." Journal of the University Film Association 28, no. 2 (1976): 17.

${ }^{45}$ Ibid. 18-19.

46 "Newsreel: Film and Revolution," cinéaste 5 (Spring 1973): 7-13.

${ }^{47}$ Alcoff, Linda. "The Problem of Speaking for Others." Cultural Critique no. 20 (1991): 6-7.
} 
The religious and reverent aspects of the LDS Church were something I had to account for in the making of COMET. And the observational techniques I began the project with worked well with this aspect of their reality. What became important to understand was how to capture gesture when shooting in an observational mode. I was first curious about how gesture can shape an image, after studying the work of Richard Kalvar, a major photographic influence during the preparation for this project. Kalvar's work is defined by gesture, on either a micro or macro level. Whether it is the shape of a face or a body's position, gestures define the photograph outside of its contextual or narrative faculties. The gestures I was drawn to during COMET were those of reverence, discipline, order, and solidity. Figure 1 and 2(see Appendix 2) within COMET exemplify this. Let us consider Figure 1, After a Loss, which pictures one of the Comets crying after having lost their exhibition game in Sandpoint, Idaho. His head is bowed, and his fingers are clutching the chain link fence outside the locker room, as fans are beginning to walk by. During the exhibition, viewers had asked me if he was either praying or crying. The gesture here gives the image mobility, as it creates options for the photos internal narrative. Both options, prayer and crying, apply directly to the faith and sport elements of the larger narrative and theme of the sequence. Figure 2, Before Dinner, depicts Elder Ashton praying in the car before they go and join one of Raymond's families for dinner. His head is bowed, his hands are clasped, and his eyes are closed. This gesture is indeed of prayer, and it connects with the image of the crying Comet before it, although the topic is strictly religious. Figure 3 and 4 speak to a different element of the manner in which gesture operates (see Appendix 2). Figure 3, Brady's Jacket pictures Brady Baines pulling on his "Comets" letterman jacket after seminary class (LDS-run high school religion class). It is an image that felt staged or posed to more than one viewer. The shape of the image, defined by his turned back and tilted head, with Brady positioned in the middle of the frame, is a position that, through its gesture, signals a certain reverence for the garment he is about to wear. It also shows his individual presence within a larger group, and functions emblematically as a title for the entire project. Figure 4, Warm-up, pictures Comet linemen performing their group warm-up before the season home opener. Their collective gesture and almost-synchronized footwork shows order and addresses the reality of existing as individuals in relationship to the group, something present in both sport and community life. Sequencing these different images through gesture creates a connection that both informs the seriousness of their sport, and clearly visualizes the reality of their faith. For 
me, making gestures prominent was a method of enhancing the observational approach to photography, with the hopes of adding a visually distinctive element to help the viewer identify connections between both the images and their concepts.

Throughout my trip I found it necessary to adjust my methodology. I had to learn to facilitate moments, in order to help make sure I was in the correct situation to show the reality of Raymond. This began the implementation of the idea that one can nudge, but can never push their way into creating a document. As a documentarian, I had to learn to take what I was given. In a town where pure observation would not work due to the private nature of the town, there is the necessity to nudge, in that you have to ask to be present, in order to position yourself in a position to be able to find what is relevant. This creates the opportunity to make the unknown visible on the subject side of the documentary. The documentary theorist Calvin Pryluck, contended that in documentary situations, the "...method of obtaining consent is stacked in the filmmakers favour." ${ }^{48}$ In this situation, I had no advantage for getting access, with the unity of the town operating as almost one subject. There were also no perceivable problematic imbalances, a potential issue that Pryluck raises in reference to documentarian Frederick Wiseman's work, such as Titicut Follies, where Wiseman filmed within a hospital. ${ }^{49}$ Working cautiously, I witnessed the clashing and tension of this community in their decision to perform what could be otherwise be seen as authentic.

The methodology changes that were applied from the first period of my time in Raymond were fundamentally beneficial. I had to understand that in asking these people if I could be present or participate in key events in the life of this town, the events themselves were performed, or at least performed unintentionally, in that they were dedicated moments rather than fluid events. These moments registered images that were truly observed, but lived within a different framework. In creating these photographs, and in an observational style, I had to learn my position: that the act of surrendering pure observation could occur well before the firing of the shutter. In talks with one of my contacts in Raymond, the topic of guns arose. There were some loose promises that we would go skeet shooting, and in my excitement to try something

\footnotetext{
${ }^{48}$ Pryluck, Calvin. "Ultimately we are all Outsiders: The Ethics of Documentary Filming." Journal of the University Film Association 28, no. 1 (1976): 22 .

${ }^{49}$ Ibid.
} 
new, I followed up with him, and we went clay shooting. It is a small example, and I was not necessarily forcing a moment such as this, but it was not perfectly natural either. The results of these arrangements are moments that are specifically shown. Their reality comes into contact with their desire to control the story from the outside world. A type of invisible performativity occurs when this happens. This is essentially a mode of pre-editing, on the part of this community. James Linton writes about documentarians attempting to make their work collaborative by giving the subject (at least partial) control of the edit. The issues raised remain valid, such as a desire by the subjects to control their own visual image and portray themselves in a more positive light. ${ }^{50}$ The important consequence that Linton finds is the relationship between the subjects pre-existing power, and that of editorial control. The more power a subject has, the more they are motivated to control the story in order to seem more favourable. ${ }^{51}$ I was never asked to edit these images particularly, or present them in a certain way. But the overall situation, and my necessity to ask to be present, versus simply being present and observing, gives Raymond the ability to pre-edit, wherein they control at least a certain amount of how they will be portrayed. It is smart and not unnerving in my opinion, as it shows their awareness regarding the power of portrayal, and the weight that images can carry. But I believe that in that performance lies the root of their communally and religious performativity itself. I learned that my method for thinking about the images was defined by the fact that involvement, even at the early stages, affected the way things were presented in a place where nothing happens, and people who are cognizant of the presence of the photographer or documentarian. This was also true in the case of their high school religion classes. They were all fairly identical each time I visited, with different video versions of the foundation of the Mormon Church being played, as well as different games and exercises creating a light-hearted and welcoming atmosphere. Wanting to demonstrate their beliefs optimally shows they desire to control a part of their representation.

During my trip to Raymond after the Christmas season, a similar situation was presented to me. Based on my own personal feeling and the feedback I received during the critiques at the end of July 2018, it was clear that I needed more religious imagery in my work, and I believed this to be a good approach to be around that aspect of life more, outside of the seminary

\footnotetext{
${ }_{51}^{50}$ Linton, James M. "The Moral Dimension in Documentary." Journal of the University Film Association 28, no. 2 (1976): 20. 
classroom. My contact in Raymond, the teacher of religion classes for the Raymond High School, Dan Bikman, was very helpful in organizing members of the community, and arranging moments to shoot. My goal for January 2019 was to visualize this town's religion in more detail. It was arranged for me to go to what was described as a group prayer event that occurred after the church service ended on Sunday. My contact within the church set me up to meet a family at their home, whose son Payson Hill was on the Raymond Comets football and basketball teams. This type of moment is the downfall of operating in a largely observational style, even if you gently nudge reality. When arranging meetings is necessary, a photographer has to take what is given to them. Namely, the fact that you can't push for information, you cannot make people do things out of the ordinary, but you can nudge them to get them going. The second meeting I had set was spending a day with the LDS Missionaries, who the Church had sent to Raymond. This was more optimal and I was happier with the images that were produced. But, this again is a situation where what is shown is the extent of what can be known in that moment, while still maintaining an observational position. The reality is that, the presentation, the performance, is the root of what is true. In this moment, there was an awareness of the camera and an presentation of oneself, in what documentary theorist Thomas Waugh would term a “"presentational" performance." line for people who define themselves strongly with one group or way of life, and want to protect that.

Moving forward in the final steps of my methodology, it is important to break down the process of making my technical decisions, as there were a number of technical elements that I regarded as fundamental to my methodology in creating this project. Many of these technical decisions were based on what I was most familiar with, in order to feel more comfortable about how the project was being shot. For starters, the decision to utilize colour photography is based on the strong colour palette of the Comet football team, as they have a pronounced red and white scheme. I believed this to be absolutely necessary as a sort of visual marker that pronounced itself in relationship to the other modes of life in Raymond, as well as the environment around it. The decision to shoot digital images was another element that was purely practical. I learned to shoot photographs on a digital camera, and while I could have practised shooting film

\footnotetext{
${ }^{52}$ Waugh, Thomas “Acting to Play Oneself: Performance in Documentary (1990). In The Documentary Film Reader : History, Theory, Criticism. Ed. Jonathan Kahana,. New York: Oxford University Press, Incorporated, 2016. 818.
} 
photography, I did not believe my final project would be the time or place to raise the chances of unnecessary technical errors.

The most notable technical decision that was made was the choice of lens length. I shot the vast majority of the project with a $28 \mathrm{~mm}$ lens mated to a $35 \mathrm{~mm}$ digital full frame sensor. When I was practising photography before I entered this program, I shot my images with a camera that was a cropped (APSC) sensor, combined with a $18.3 \mathrm{~mm}$ lens, giving the images a $28 \mathrm{~mm}$ equivalent field of view. However, when upgrading to a true full frame camera, the $28 \mathrm{~mm}$ I had become used to on the smaller camera was now stretched, and seemed much, much wider. When I started shooting photographs, there was an element of the shots where I wanted to be close. Part of that is undoubtedly because of the very famous Robert Capa quote "If your pictures aren't good enough, you're not close enough." ${ }^{, 53}$ And Capa's photographs seemed quite good, so I believed him. But that was only a tiny part of it. Part of this influence was an interview between Al Pacino and Christopher Nolan regarding the production of his 2002 film, "Insomnia." Nolan says: "...for me the important thing about deciding where to put the camera ... is, I like to think a lot about how close the camera is to the person. And I believe that the audience on some level, is aware of that distance. ${ }^{54}$ So there's a scene in the film where you [Pacino] make a telephone call ... and I remember when you came in to sit down to do the scene, you were pretty surprised at where the camera was because it was pretty close to your nose on a $75[\mathrm{~mm}]$... these days that's a little unusual, people tend to want to have longer lenses, cameras further away, but I think that creates a distance and I think that you don't get that intimacy." interesting influence for my method that has been in my process for years. This approach affected COMET, most notably in its strictly football photographs. Traditional sport photographs are shot with long lenses, but by shooting photos of sport more holistically (in action vs. inaction shots) there was the potential to move closer. This reduced distance is the defining technical difference between these two types of images. Figure 8, Pregame (see Appendix 2) of COMET, where Parker Sillito is staring up at coach Darryl Salmon while he addresses the team during the pre-game, is an image that not only benefited from, but actually required a closer approach.

Proximity cannot be faked, and the audience can tell that the camera is close. I believe that same

\footnotetext{
${ }^{53}$ Magnum Photos Photographer Profile. Robert Capa.

https://pro.magnumphotos.com/C.aspx?VP3=CMS3\&VF=MAGO31_9_VForm\&ERID=24KL535353.

${ }_{54}^{54}$ NolanFans. YouTube. August 05, 2009. https://www.youtube.com/watch? $\mathrm{v}=9$ ryMJzODDIs. 8:42-8:55.

${ }^{55}$ NolanFans. YouTube. August 05, 2009. https://www.youtube.com/watch? $\mathrm{v}=$ oyhNAmiPjo0 $. ~ 0: 13-0: 29,0: 35-0: 43$
} 
approach works with photography. You cannot emulate being close. This proximity becomes inherent to the image, and creates a different sort of immersive value for the viewer. I had to trust that these images would register as "close" and help the viewer enter into the scenes, especially since I was working with a wider field of view.

The images were printed at 39" x 26." To achieve this, the digital files needed to be prepared to print larger than their native resolution. ON1 Resize software was used in order to interpolate the image to maintain clarity at the specified dimensions. The ability to print at a larger size, as close as I could go to 30x40", but with very high resolution (300dpi) enabled my proximity while shooting the image to be made clear. This combination of lens length, proximity, resolution, and print size were the defining technical factors that allowed for the sense of immersion to be achieved. This could be seen in two different images from the project (see: Appendix 2). Figure 5, Seminary Class, where the students are in Seminary, and one boy in the centre of the frame has his head tilted, is a clear example. The image requires a large print to properly embody the wide angle, and the resolution of that print reveals the details, and thereby the proximity of the camera. This proximity also informs the narrative, as through it, details such as the identifiable presence of Bibles and hymnbooks, and major Mormon sites on the wall are made visible that help reveal more information both about the immediate scene and the narrative of the project. This is a similar type of approach that is taken in Figure 6, Team Bus (see Appendix 2), where the photographs of the boys on the bus after winning their game against their rival town, Cardston. The image benefitted from this immersive combination once again; the width of the frame, combined with the resolution and the proximity of the camera, made into a large print reveals the environment of that reality. Because of the detail and size, you are not only drawn to the gaze of the player, but also to his friends around him, who are looking at the camera from the background. Without this immersive combination of technical factors, these images do not work as well, especially in the gallery space. The images were hung with wire and mounted on $3 / 4$ " MDF board (medium-density fibreboard), then plaque laminated with a matte finish in order to reduce reflections. This decision was primarily based on its combination of cost effectiveness and quality. Framing everything was prohibitively expensive, and the plaque mount had good rigidity, with applied matte lamination being effective as well. 
Outside of the images, the text for this project was kept to a minimum. This was done so that the photos inform the text, as the photographs are the primary document in this project. There is a list of conceptual approaches that I considered, regarding a heavier inclusion of text in the gallery to help shape the space of the work for the viewer. Ultimately, I felt the best decision would be to reduce the text element: if it could not have been a carefully implemented major aspect, it would have to be a very small part of the installation.

The development of the sequence of this project was crucial, as it was necessary to balance the essential images with one another, while combining them with a didactic text on the wall. The sequencing process took multiple attempts and revisions, and was worked on for quite some time. The process for selecting the right photographs was based on the rule of utilizing the absolutely best images I had available to me. There were multiple revisions in the planning stages, with the working document included in Appendix 1. I was intent that sequencing was to be done digitally, as having the outline of the gallery to drag images onto was indispensable. The ability to move elements fluidly is something I found necessary, as the sequence is locked to the space, and quickly visualizing is something I found to be completely effective when working with the final installation. The progress of selecting these images came from the desire to introduce the viewer to the images slowly, familiarizing them so as to have a stronger foundation to work from. It was necessary to make the language of gesture clear within the work, emphasizing the idea of this reverence early on, in order to establish it for the rest of the images. The sequence was built on a left to right "track" in the space, a decision made based on the openness of that side when entering. The left side matched with the introductory images, and the floating walls that were utilized paired with the more specific images used in the second half of the gallery. The first half, as an introduction, had the short didactic piece and images that were generally not quite as close in proximity as in the second half. This specificity was strengthened after the viewer became familiar, or at least had an idea of where and what they were visualizing. Some key images (available in Appendix 2) that help define the sequence are Figure 1 and 2: After a Loss and Before Dinner. These images, occurring immediately after the didactic section, become a good connection point for visualizing the introductory panel, showing how "...sport is a mode of faith" (See: Appendix 1), quickly showing both themes. Another crucial pairing is Figure 7 and 8 (see Appendix 2). Figure 7, Dinner Prayer, is important, as it is a clear showing 
of the religious element, from a more classical perspective, with the Mormon Missionaries for Raymond praying before dinner. Figure 8, Pre-game is the image of the pre-game moment, the calm before the storm. This pairing speaks to the aspects of preparation that occur, whether religiously or athletically, in this reality. Sequencing for COMET was defined by a flow of images defined by the continuity of gestures that informed the viewer of the nature and connections between Raymond, faith, and sport overall. 


\section{DOCUMENTARY RELEVANCE}

The documentary relevance of COMET is concerned with two key points. Firstly, it looks to be a document of an embodied idea, versus merely capturing an event or occurrence. This moves it away from being a purely photojournalistic project. Secondly, it approaches the pragmatic elements and implementation of religion, a reality not common for most. ${ }^{56}$ The project is not about observing religion as a spectacle, or revelling in its strangeness. Shelby Lee Adams' Appalachian Legacy is a project that operates in this manner. ${ }^{57}$ Rather, COMET is about how sports can be functional, as an indicator of a larger way or philosophy of life and in this case, life mixed with religion. I believe this approach works for my project, as visualizing the story through images that are not sports photographs in their genre or nature, provides an opportunity for the viewer to enter into their visual reality, both in the subject matter, theme, and shape of the project.

The visual approach for the first phase of this project came from the desire to create highly observational images. This was at a time when I was approaching the project with preconceived notions of an existent Mormon visual reality; missionaries all over town, with white shirts, ties, and nametags. And in my first trip there, things did not turn out as such. Rather, there is a quiet reality to this town, and its devotional element does not have a strong Mormon visual tradition. It took time for me to learn that in order to deal with this, a change of technique would be necessary.

Examining football as a manifestation of religious and social reality in Raymond, is a much more effective approach. I believe it affords me space to explore further, removing my conceptions of this space, and not playing into what I want the project to be. As said earlier, sport as a manifestation of devotion is something that does not allow for a journalistic approach. There is a certain level of nuance required, in order to help make it unique in the history of sports representation. H.G. Bissinger's Friday Night Lights, with photographs by Robert Clark, is a

\footnotetext{
${ }^{56}$ Statistics Canada. "Canada Goes Urban." Women and Paid Work. May 17, 2018. https://www150.statcan.gc.ca/n1/pub/11-630-x/11-630x2015004-eng.htm.

${ }^{57}$ Adams, Shelby Lee. Appalachian Legacy. University Press of Mississippi, 1998.
} 
prime example. ${ }^{58}$ Typically, sport influences the reality around it. But that is not shown in traditional sport photography. The great photos of sports are always about something other than what is going on in the image. Clark's images for Friday Night Lights were a great starting point, as they embodied scenes that I personally knew from competing in football for most of my life. They were photographs that were more human-centric, that pictured the essence of deeply human moments through competition in sport. The very famous photo of Muhammad Ali standing over Sonny Liston is one that that tells a story of victory and dominance. ${ }^{59}$ Mickey Mantle walking back to the dugout after striking out with his head bowed, tells one of decline. ${ }^{60}$ The images here are not meant to be literal, but to function at a connective or connotational level. This project gives a chance to understand certain sport truisms that are often brushed off. The ideas of obedience and doing your job, sacrifice, and being selfless in the pursuit of a larger goal, are built-in requirements of successful sport, that are essentially more theological than athletic. This project is one that observes the lived-out reality of sport as evidence of larger concepts, and helps recontextualize what sport can be in the viewers mind.

Part of my approach came from understanding the importance of specific places in this town. One has to be present in relevant and important locations, as the approach of spontaneous street photography does not work the same in a small and quiet Mormon town; I had to get closer to faith and family, being present in religion class, missionary rounds, and a players home. The influence of Tim Hetherington's photo book Infidel, which tells the story of one American Military platoon in Afghanistan's Korengal valley, was revelatory for me. ${ }^{61}$ Essentially, Hetherington tells a war story without depicting combat itself. He utilizes war as a backdrop to examine masculinity, ${ }^{62}$ although I argue that the images are about the performance of soldier hood, presented through the guise and format of the family photobook. Portraying a specific reality showing certain images, in order to communicate a deeper and broader concept is a definite approach of Hetherington's project. The relationship that COMET has with documentary is of a similar design. It lives in conversation with a type of non-literal photography that utilizes

\footnotetext{
${ }^{58}$ H. G. Bissinger, Friday Night Lights: A Town, a Team, and a Dream. Da Capo, 2015.

59 "Muhammad Ali vs. Sonny Liston | 100 Photographs | The Most Influential Images of All Time." Time. http://100photos.time.com/photos/neilleifer-muhammad-ali-sonny-liston.

60 "Mickey Mantle, 1965: A Classic Photo of a Great Athlete in Decline." Time. http://ime.com/3879887/mickey-mantle-1965-a-classic-photoof-a-great-athlete-in-decline/.

${ }^{61}$ Tim Hetherington, and Sebastian Junger. Infidel. London: Chris Boot, 2010.

${ }^{62}$ Rob Haggary. "Tim Hetherington's Last Interview." Outside Online. October 29, 2015. https://www.outsideonline.com/1825916/timhetheringtons-last-interview.
} 
its context to relay to the viewer a deeper narrative. The effect that the "New Journalistic" approach had on this project was also foundational to the development and process it took to create COMET, specifically in the movement away from merely descriptive photojournalistictype images. The goal of the "New Photojournalists" (NPJ) was to "convey more complex and sophisticated meanings, of both a social and personal sort, and to this end they want to control the contexts in which their images are presented. They also want to receive credence as creative photographers. ${ }^{, 63}$ Tim Hetherington's work in Infidel showed this precisely, and presented a genre-mashing narrative where the images are not abstract and were descriptive enough to be understood, but were used as signifiers for a larger concept. In COMET, the images and the shape of the project was defined by similar priorities. The behind the scenes nature of Hetherington's project, allowed the viewer to witness the cogs of the wheels of war, hyper specific and localized to one place: Outpost Restrepo ${ }^{64}$ COMET, in both its approach and final sequence had to deal with an arguably larger space and concept, the entire town of Raymond and the function of belief. The influence of the NPJ's was crucial in understanding the liberty of sequencing and selection, as this was not merely a photojournalistic project. This movement away from literal and concrete progression was both freeing and stabilizing, as it gave a conceptual direction to head towards. Because of the lack of public religious ritual within the Mormon faith, and the prohibited nature of their services from being photographed, ${ }^{65}$, a nonliteral progression is both welcome and necessary. Part of the goal of showing what did not publicly exist was to create images which, like in Infidel were definitively unabstracted, but were not merely links in a chain. For example: in a film, the succession of many similar frames create movement and story; the distance between each frame has to be extremely close for anything to be seen. In photography, and in utilizing the type of fluid and creative narrative approaches that the NPJ approach espoused, the distance between each frame can be wider in subject and form, as long as there are enough connections in either the images content or shape to render the narrative coherent. In this difference and non-uniformity of theme and content, the space between begins to fill with potential connections, and in these connections lies the narrative, message, and seen reality of Raymond. The space between is where the meaning lies.

\footnotetext{
${ }^{63}$ Andy Grundberg, "The "New Photojournalism" and the Old," in Crisis of the Real: Writings on Photography. Third Edition, (Aperture Foundation, 1999), 185.

${ }^{64}$ Hetherington, Tim, and Sebastian Junger. Infidel. London: Chris Boot, 2010.

65 "21. Selected Church Policies and Guidelines." 21.2.10 https://www.churchofjesuschrist.org/study/manual/handbook-2-administering-thechurch/selected-church-policies-and-guidelines/selected-church-policies?lang=eng.
} 
There are several documentary photo projects that informs where COMET sits in the documentary context, regarding the representation of its balances between sports and life. Alice Mann’s Drummies project, a photographic series capturing “...the unique and aspirational subculture surrounding all-female teams of drum majorettes in South Africa", is a very valuable and informative reference. ${ }^{66}$ Mann manages to give shape to a narrative that consists of simple parts. She communicates place and action in these images, and the viewer finds the rest. This project is a great example of the manner in which a project can operate quietly, and how projects can be left with enough "air" around them, in order to keep them accessible to the viewer (not overly specific), and still able to be shaped by the artist through description and dialogue. "What the Arlee Warriors Were Playing For" is a more journalistic project by Abe Streep, written for New York Times Magazine in April 2018. ${ }^{67}$ The story is about the Arlee Warriors Basketball team, in Arlee, Montana, the reality of playing basketball as Aboriginal Americans from a reserve, the relationship between their lives and sport, and how they navigate that reality. The photos, taken by David Yalkin for the New York Times, are also an important part of this work. This project was recommended to me as a way of examining life within a sporting community, but also from the technical sense. The photographs are a combination of both observational and more black-and-white, journalistic style shots, as well as casually posed portraits that give a greater sense of who these players are. The work is definitely influential; both in the way that Streep crafts the narrative, and Yalkin's photographs compliment it. The value lies in their organizing how to set up a narrative with identifiable characters and a definite setting, that I find very useful here. Andrew Borgya for the New York Times has authored a number of publications on the New York Times LENS blog. Amanda Berg's project "Carolina Phoenix" documents the reality of Women's Football Alliance for a whole season. ${ }^{68}$ Berg combined her interest in both gender and football: "My work clearly takes advantage of the fact that football is the most masculine of games ... The only reason it seems exotic at all is because women still have such a lack of access to what we consider "masculine." "69 It becomes clear, both through the images as well as Berg's approach to her project, that her images render football as something more

\footnotetext{
66 ""Drummies"." Alice Mann. http://www.alicemann.co.za/drummies

${ }^{67}$ Abe Streep. "What the Arlee Warriors Were Playing For." The New York Times. April 04, 2018.

https://www.nytimes.com/2018/04/04/magazine/arlee-warriors-montana-basketball-flathead-indian-reservation.html.

${ }^{68}$ Boryga, Andrew. "Everybody Hit Somebody." The New York Times. April 07, 2015. https://lens.blogs.nytimes.com/2015/04/07/everybodyhit-somebody-2/?mtrref=www.google.ca\&assetType=nyt_now\#.

${ }^{69}$ Ibid.
} 
human, in that it represents a different mode of the game being played. In challenging the idea that football is defined by its masculinity, Berg is looking to insert feminism, rather than redefine football, as the sport adapts to whoever is playing it. It is a valuable project to reference, as she is moving towards breaking down layers of reality, in the preconceived notions of what a structure is. COMET fits well into this tradition and relationship with a project like Berg's, as she creates images that are primarily feminist, within the framework of sport. And although her work is not as outright in its clarity regarding sport as a mechanism for a larger concept, it is of the same documentary vein that I hope to occupy. Borgya also wrote about the work of Vasiliy Kolotilov in the same blog with the title "Overtime with American Football in Russia.,"70 Kolotilov's photographs are of a Russian men's football team, the Spartans. While Kolotilov's work itself is only about the behind the scenes approach, it again reinforces the idea that the value of projects such as this, comes when the photographs touch close to the everyday lives of the players, and their surrounding reality.

The relevance of COMET is defined by its dual relocation of genre. COMET challenges sport photography, in that it moves the needle towards the player and the community that supports them. And it aligns itself with the work of the New Photojournalistic tradition, in that it works as a documentary while denying the hard-coded concrete structures of photojournalistic literalism.

\footnotetext{
${ }^{70}$ Boryga, Andrew. "Overtime With American Football in Russia." The New York Times. November 16, 2016. https://lens.blogs.nytimes.com/2016/11/16/overtime-with-american-football-in-russia/.
} 


\section{CONCLUSION}

The question of "Why are they so good" was the driving force regarding my personal thoughts and feelings towards the Comets. My background and history with Raymond was one situated between a fairly extensive knowledge of the sport they played, and a level of success I had never achieved on any of the teams I had been a part of. The disparity between these was enough to keep Raymond in my mind, as the difference in quality was astounding. It made me ask questions and attempt to imagine a situation where success like that of the Comets could not only be achieved, but achieved in a way that appeared to be automatic, approaching effortless. My own questioning of these reasons led me to approaching it in my Major Research Project in this program, and the beginnings to the answers I came across were both unexpected yet compelling. After shooting the project and being present with the team for a portion of the season, the foundation of an answer was beginning to become clear. Players who play faster, smarter and more cohesively are not simply playing for themselves. And after reading their texts and research surrounding the Mormon faith in more detail, the importance that they place on sport as a tool for their faith, working both internally as a faith-building tool, and externally as a method of evangelization, became much clearer. And most of all, sport is a liturgical act for the Comets. It is an unofficially religious ritual that is being practised collectively, that both strengthens their internal faith, and communicates to both spectators and opponents the value of their religious systems, through victory.

The execution of this project was a great learning experience for me. The process of learning how to prepare for a project, the considerations and elements that need to be factored in before and during the experience of shooting, and the organization and synthesis of the material that was generated was a formative one. In addition to the actions that have to be taken to produce documentary work, such as the emails and phone calls and visits, there was a mental posture that needed to be adopted in order to work properly in this space. Being present in Raymond was not merely enough. Learning to position myself to capture images in a more relevant space that would help guide the narrative (whether in a religion class or being with the missionaries) was one of the most crucial learning points for this project, and an influential lesson moving forward in documentary practise. 
The installation of the project was the final piece that changed my perspective on documentary. The importance of the work being seen, and the necessity of work to exist in a focused setting changed my impression of how a visual narrative can exist in a gallery. It also helped form my understanding of the way that a sequence and story is subjective for the viewer, after the installation process is completed. The technical process of creating the gallery installation was one that was incredibly beneficial, in that it was an education in the importance of the smallest details. Learning how to control the surrounding elements of a project, including properly implementing the text-image relationship, as well as making the physical space as cohesive and uninterrupted as possible, were examples of the importance of controlling detail. In my case, the goal was to focus on the images, and reduce extraneous elements.

The process of creating COMET was entirely formative, and was important for me to tell this story, as it was a reflection of a part of my life that was completed not that long ago.

Word count: 11,051 


\section{APPENDIX 1}

GREGRY SEVRTI

COMET LAYOUT

IX GALLERY

For JUNE 1L"'@6 pm

\section{COMET}

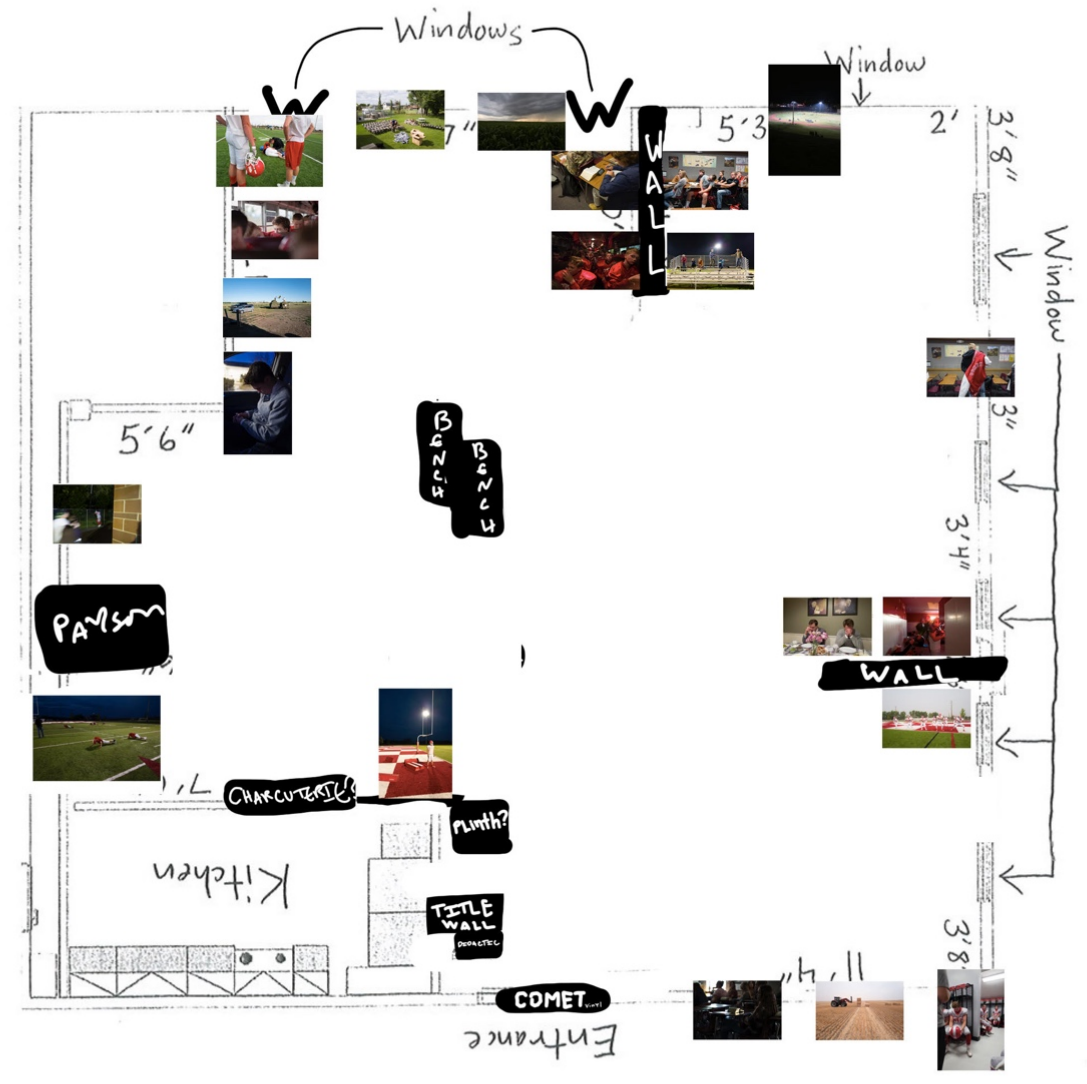

\footnotetext{
- 6eT VDVill

- clear utmpous/Floors

- charcureciefserving table

- Fond or how to cover maeels.

- Scrum unarloclear

- 6É phone JACh covier

- PIMD PLDTTH
}

Installation Progress Diagram 


\section{COMET}

Raymond is a town located in southern Alberta. Their high school football team, the Comets, are neither the biggest nor the fastest. But they have competed against metropolitan schools that hold thousands of students and large teams. And after winning seven Tier I Alberta high school football championships, they have a history of success that belies expectations.

In Raymond, sport is a mode of faith.

COMET aims to give a sense of their specific reality. The nature of Raymond is one of belief, made clear in its culture and its attitude towards sport. Resulting from a documentary approach, these images portray Raymond and the Comets beyond the sporting moment. By photographing outside of these bounds, COMET seeks to give insight into the factors that define them, on and off the field.

Didactic Wall piece 
APPENDIX 2

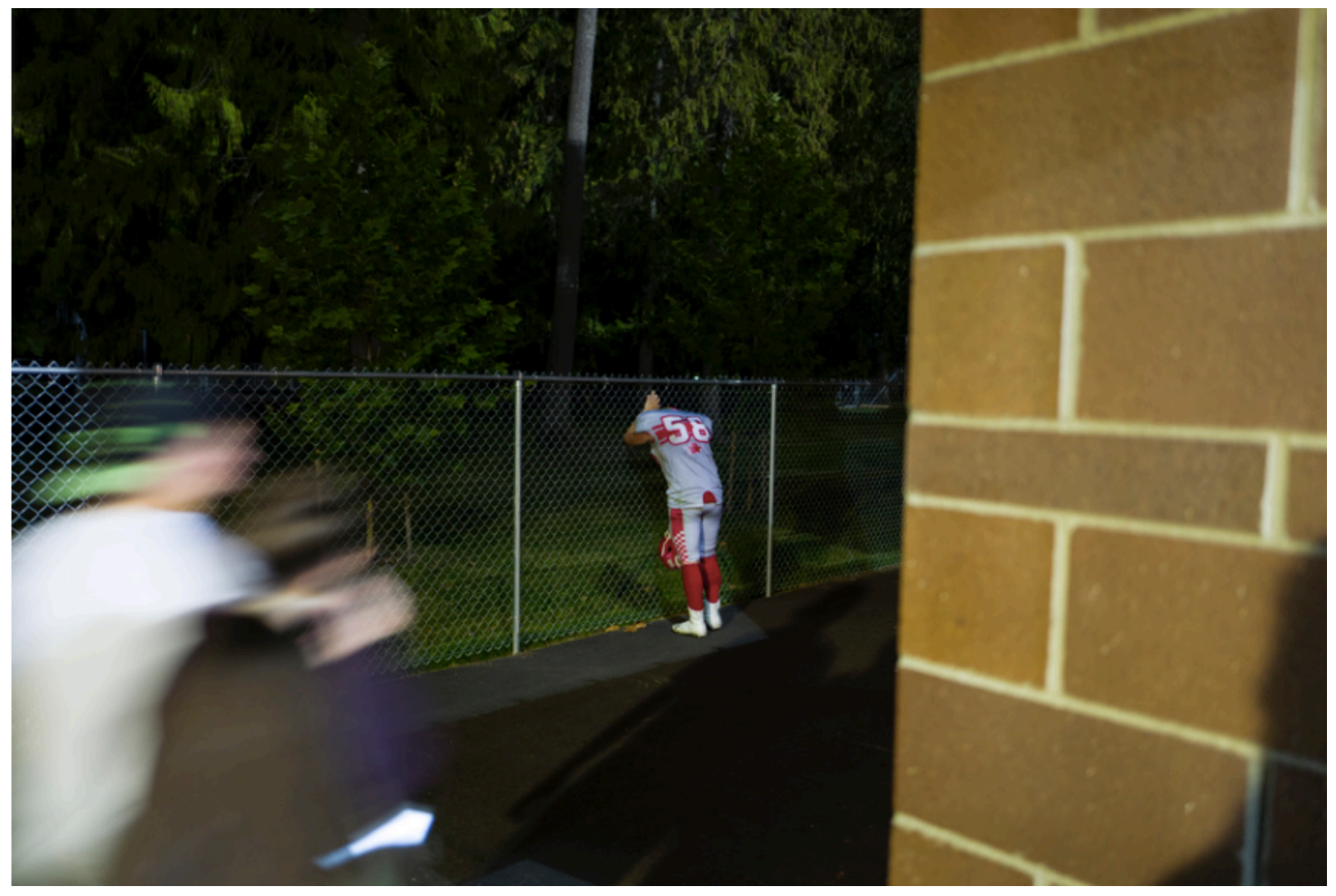

Figure 1: After a Loss 


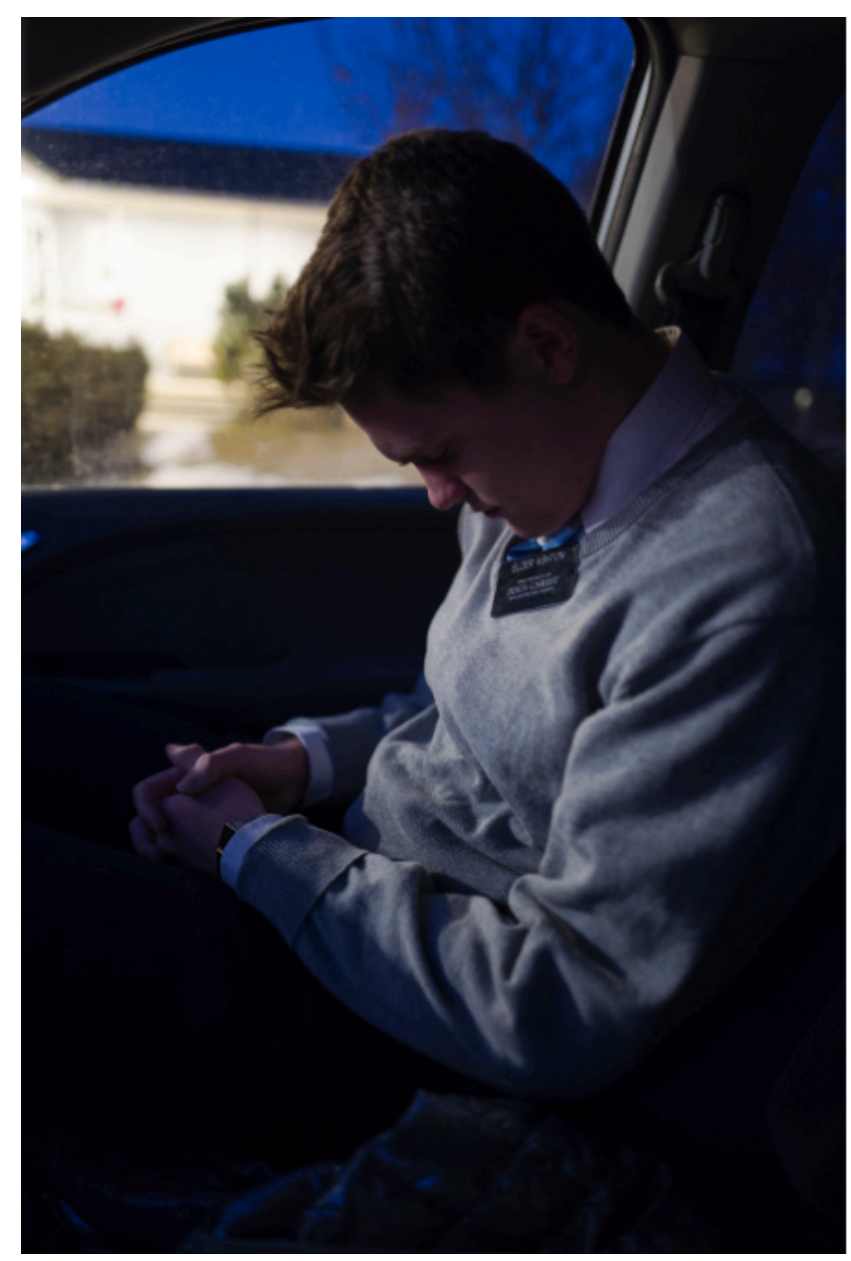

Figure 2: Before Dinner 


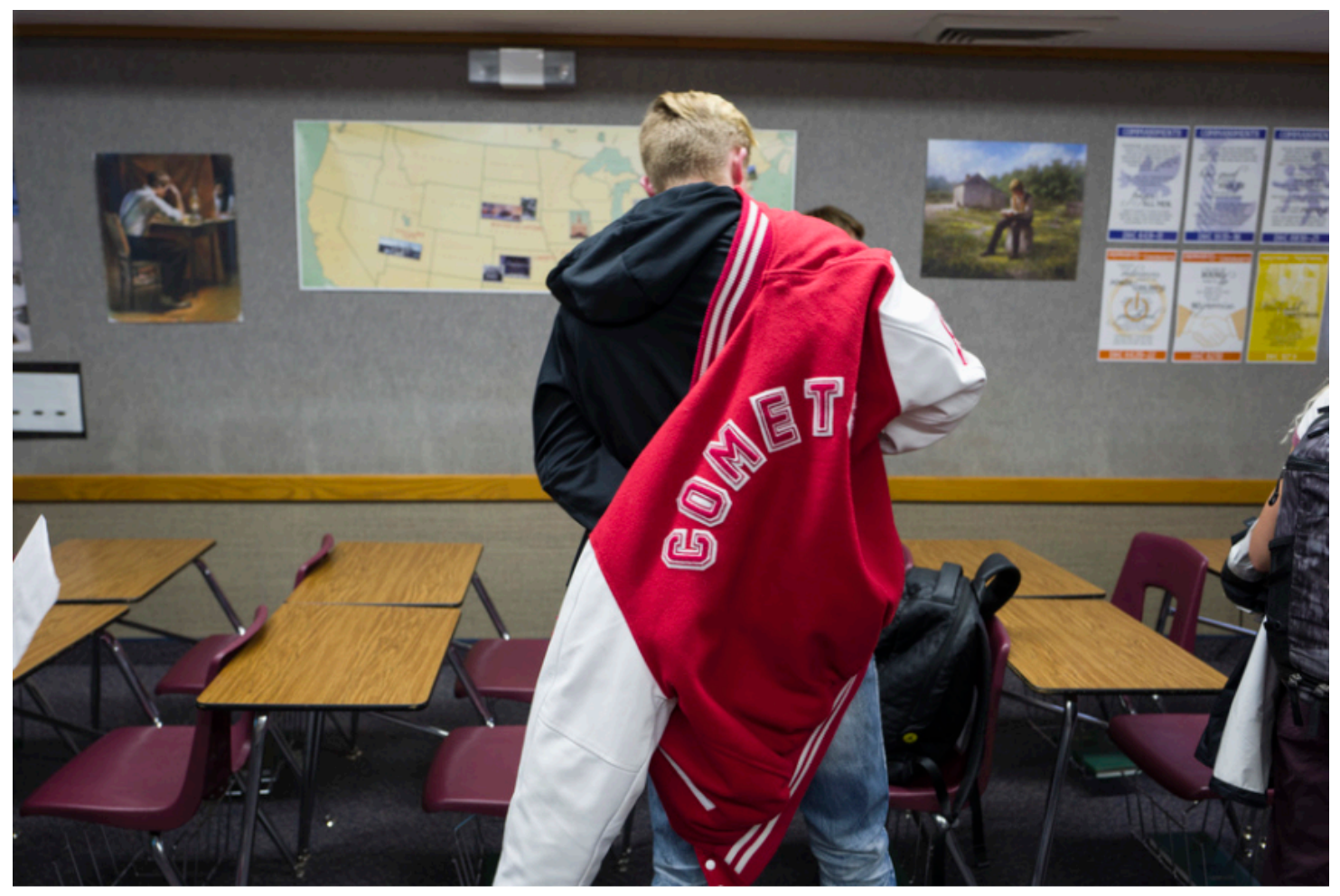

Figure 3: Brady's Jacket

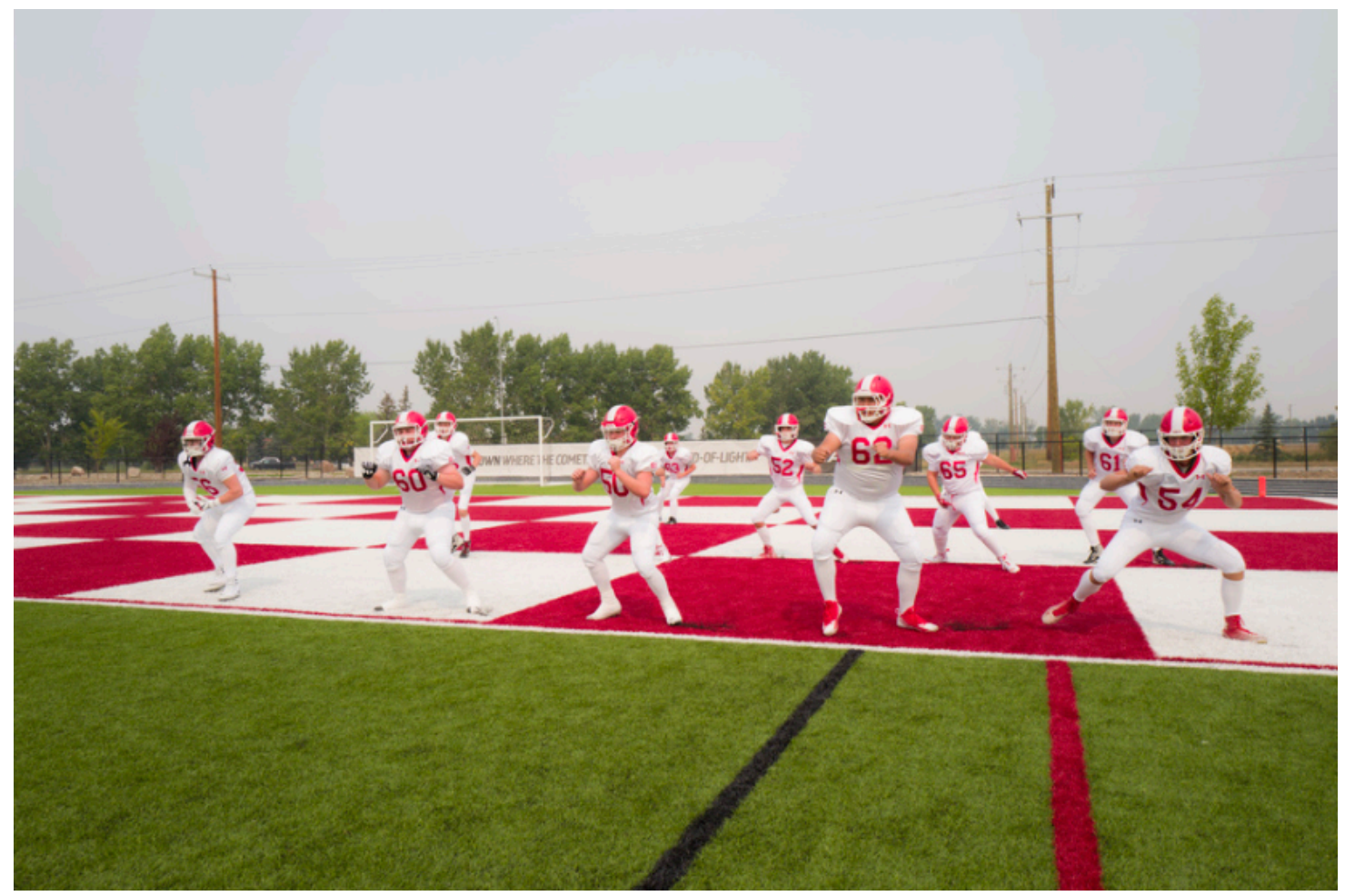

Figure 4: Warm-up 


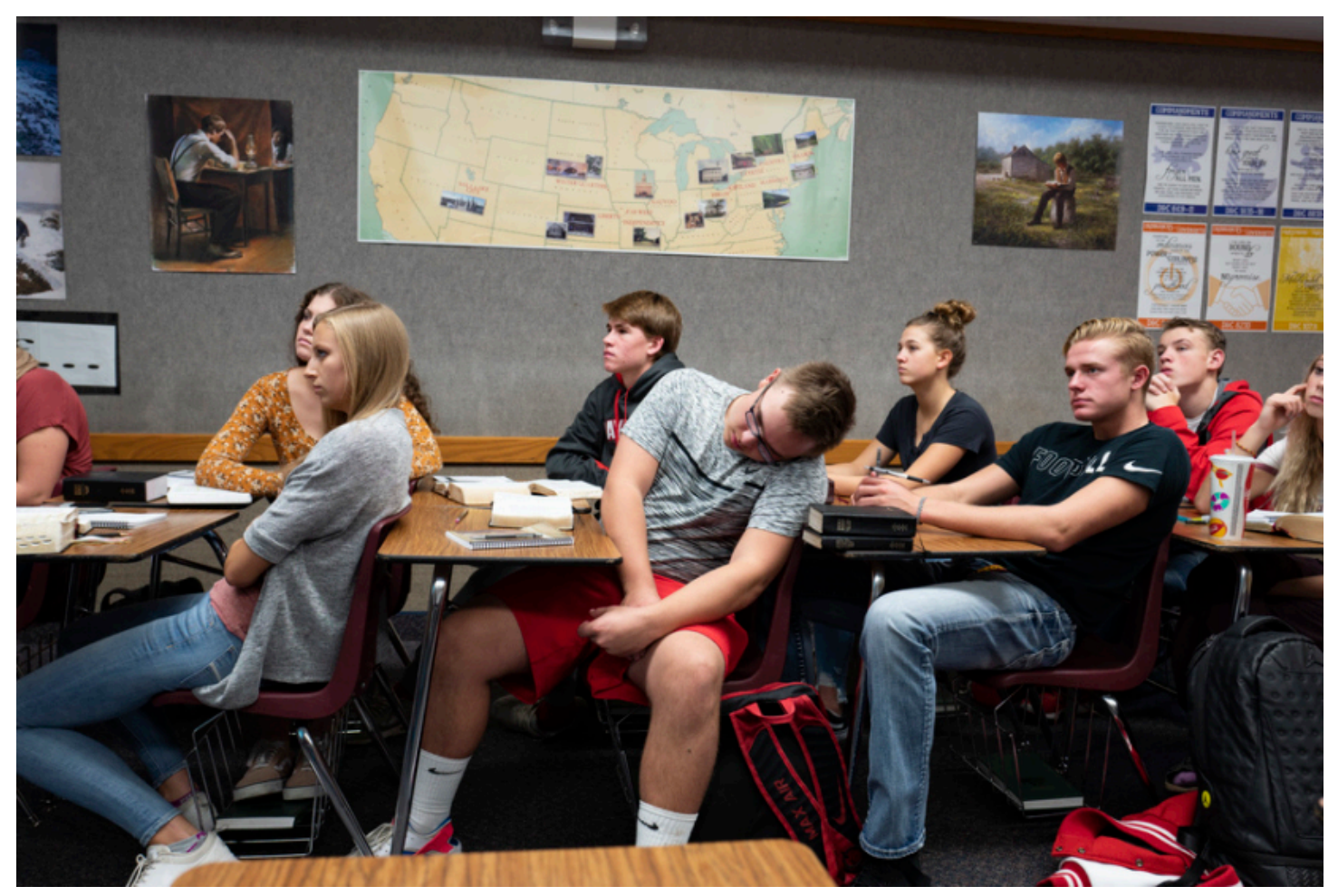

Figure 5: Seminary Class

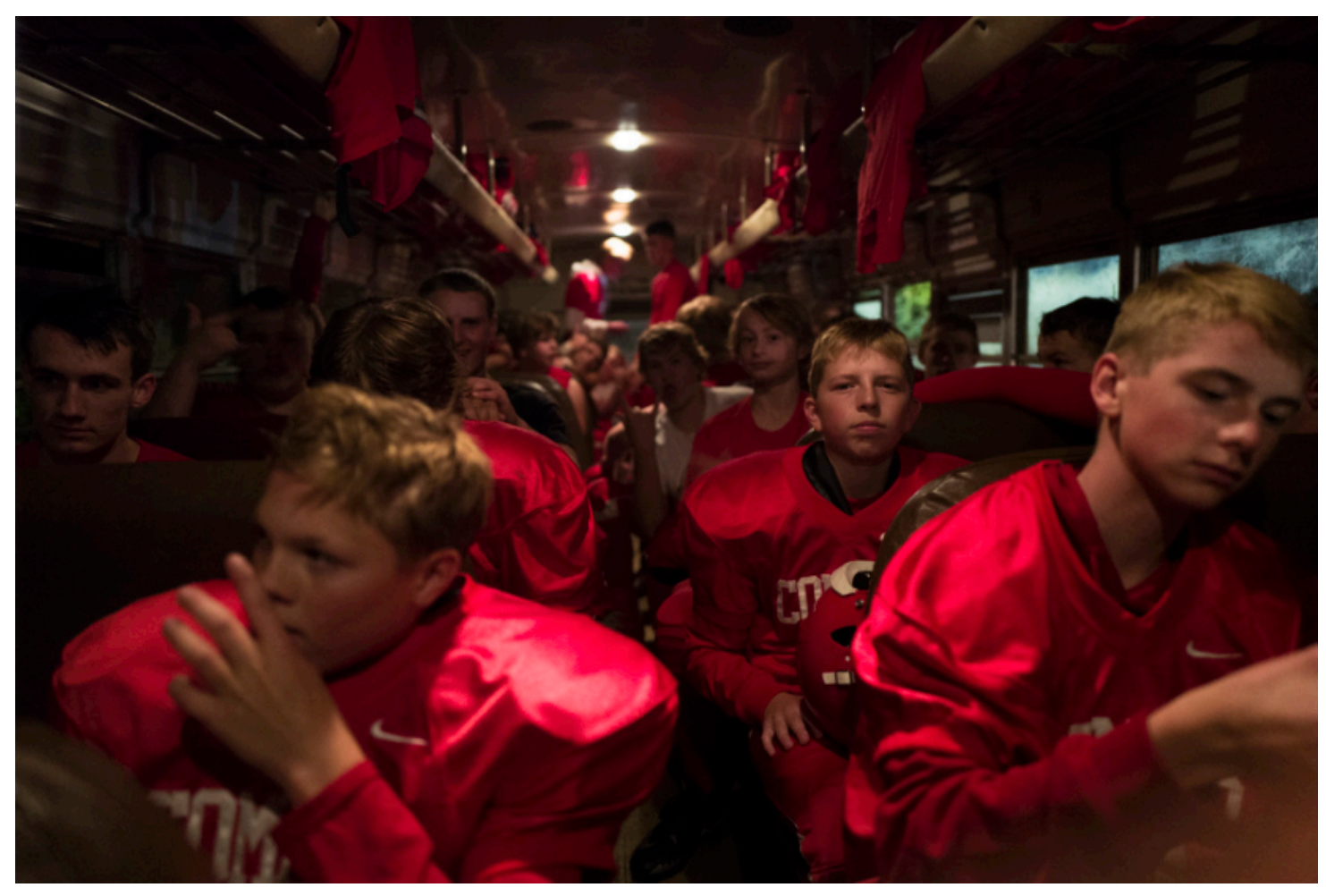

Figure 6: Team Bus 


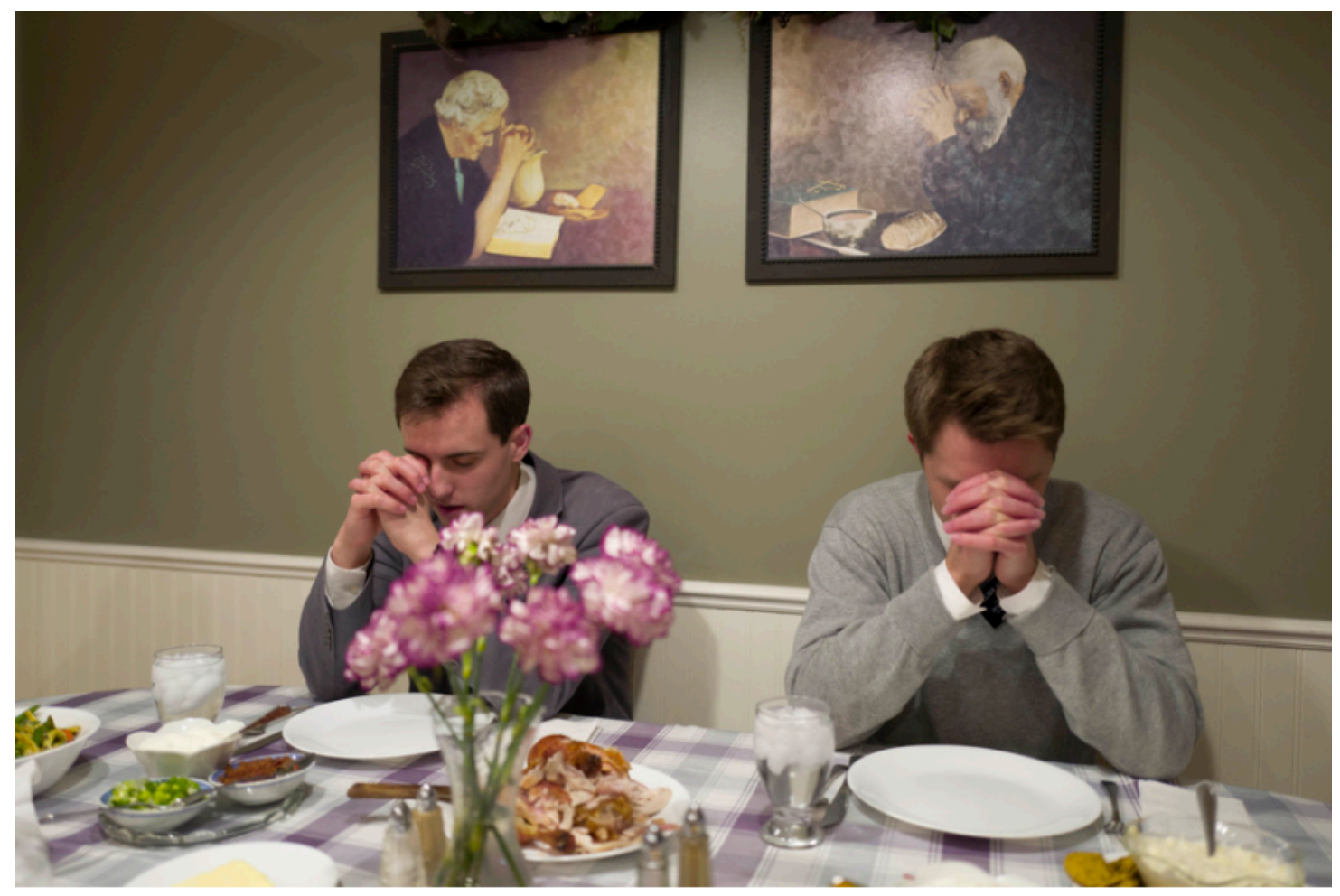

Figure 7: Dinner Prayer 


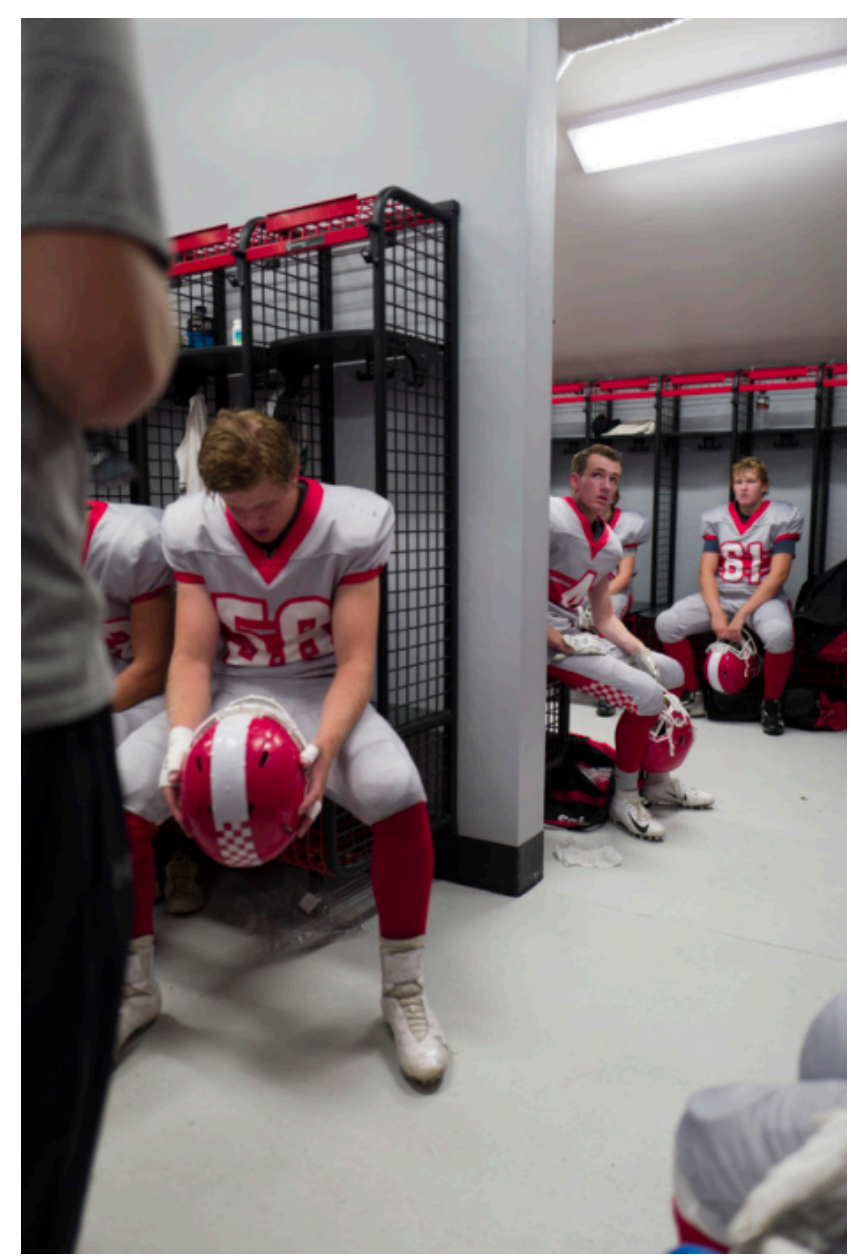

Figure 8: Pre-game 


\section{BIBLIOGRAPHY}

Alcoff, Linda. "The Problem of Speaking for Others." Cultural Critique no. 20 (1991): 5-32.

Adams, Shelby Lee. Appalachian Legacy. University Press of Mississippi, 1998.

Bigge, Ryan. "A Picture and a Thousand Words; with the Season of the Witch upon Us, a Photographer Finds the Key to Making a Strange Ritual seem Even Stranger: ONT Edition.” Toronto Star,2007.

Bissinger, H. G., Friday Night Lights: A Town, a Team, and a Dream. Da Capo, 2015.

Boryga, Andrew. "Everybody Hit Somebody." The New York Times. April 07, 2015. Accessed August 2019. https://lens.blogs.nytimes.com/2015/04/07/everybody-hit-somebody2/?mtrref=www.google.ca\&assetType=nyt_now\#.

Boryga, Andrew. "Overtime With American Football in Russia." The New York Times. November 16, 2016. Accessed August 2019.

https://lens.blogs.nytimes.com/2016/11/16/overtime-with-american-football-in-russia/.

"\#CFC50 National High School Rankings (Champions \& Runner-Up)."

CanadaFootballChat.com. Accessed August 2019. https://canadafootballchat.com/cfc-top-50national-high schoolrankings-champions-runner-up/.

COMET. Gallery IX, Toronto, Ontario. June 14, 2019

Cosh, Colby. “A Prairie Football Phenomenon.” Macleans.ca. November 02, 2011. Accessed August 2019. https://www.macleans.ca/news/canada/friday-night-lights-on-the-prairie/.

““Drummies'.” Alice Mann. http://www.alicemann.co.za/drummies 
Goodstein, Laurie. "Fletcher Stack, Peggy. Religion News Service. "Book Examines Pivotal Moment in US History: Joseph Smith's Murder.” The Washington Post. WP Company, July 2, 2014. Accessed September 2019. https://www.washingtonpost.com/national/religion/bookexamines-pivotal-moment-in-us-history-joseph-smiths-murder/2014/07/02/981ab6b4-023111e4-8bb2-6b921949ecfa story.html.

Grundberg, Andy. "The "New Photojournalism" and the Old," in Crisis of the Real: Writings on Photography. Third Edition, (Aperture Foundation, 1999), 185.

Haggart, Rob. “Tim Hetherington's Last Interview.” Outside Online. October 29, 2015. Accessed August 2019. https://www.outsideonline.com/1825916/tim-hetheringtons-lastinterview.

Hetherington, Tim, and Sebastian Junger. Infidel. London: Chris Boot, 2010.

"History of The Church of Jesus Christ of Latter-Day Saints."

Newsroom.churchofjesuschrist.org, August 1, 2016. Accessed August 2019.

https://newsroom.churchofjesuschrist.org/article/history-of-the-church-of-jesus-christ-of-latterday-saints.

History of Raymond.” Town of Raymond. Accessed August 2019. https://raymond.ca/historyof-raymond/\#history. https://raymond.ca/wpcontent/uploads/2019/04/RaymondHistoricContext14Oct31Lo-res_33f3f697a3.pd0f

Hefley, Justin J. "Perceptions of Texas High School Football Coaches regarding Concussions." Order No. 10268622, Concordia University (Oregon), 2017. http://ezproxy.lib.ryerson.ca/login?url=https://search-proquestcom.ezproxy.lib.ryerson.ca/docview/2201904593?accountid=13631. 
"Joseph Smith: The Murder of the Mormon Prophet and Subsequent Trial." Illinois History Lincoln Collections, October 11, 2018. Accessed September 2019.

https://publish.illinois.edu/ihlc-blog/2018/10/11/joseph-smith-the-murder-of-the-mormonprophet-and-subsequent-trial/.

Linton, James M. "The Moral Dimension in Documentary." Journal of the University Film Association 28, no. 2 (1976): 17-22.

Lyon, S.J. “Psychotherapy and the Mormon Faith”. J Religion Health (2013) 52: 622.

https://doi.org/10.1007/s10943-013-9677-2

Magnum Photos Photographer Profile. Robert Capa. Accessed August 2019.

https://pro.magnumphotos.com/C.aspx?VP3=CMS3\&VF=MAGO31 9 VForm\&ERID=24KL53 5353.

“Mickey Mantle, 1965: A Classic Photo of a Great Athlete in Decline." Time. Accessed August 2019. http://time.com/3879887/mickey-mantle-1965-a-classic-photo-of-a-great-athlete-indecline/.

"Muhammad Ali vs. Sonny Liston | 100 Photographs | The Most Influential Images of All Time.” Time. Accessed August 2019. http://100photos.time.com/photos/neil-leifer-muhammadali-sonny-liston.

"Newsreel: Film and Revolution," cinéaste 5 (Spring 1973): 7-13.

NolanFans. YouTube. August 05, 2009. Accessed August 2019.

https:/www.youtube.com/watch?v=9ryMJzODDIs. 8:42-8:55.

NolanFans. YouTube. August 05, 2009. Accessed August 2019.

https://www.youtube.com/watch? $\mathrm{v}=$ oyhNAmiPjo0. 0:13-0:29, 0:35-0:43 
Pryluck, Calvin. "Ultimately we are all Outsiders: The Ethics of Documentary Filming." Journal of the University Film Association 28, no. 1 (1976)

"Richard Kalvar • Photographer Profile • Magnum Photos." Magnum Photos. Accessed August 2019. https://www.magnumphotos.com/photographer/richard-kalvar/.

Roberts, B.H. 'Sphere of YMMIA Activities', 202.

Statistics Canada. "Canada Goes Urban.” Women and Paid Work. May 17, 2018. Accessed August 2019. https://www150.statcan.gc.ca/n1/pub/11-630-x/11-630-x2015004-eng.htm.

Streep, Abe. "What the Arlee Warriors Were Playing For." The New York Times. April 04, 2018. Accessed August 2019. https://www.nytimes.com/2018/04/04/magazine/arlee-warriorsmontana-basketball-flathead-indian-reservation.html.

Sumerau, J. E., Ryan T. Cragun, and Trina Smith. "'Men Never Cry”: Teaching Mormon Manhood in the Church of Jesus Christ of Latter-Day Saints." Sociological Focus 50, no. 3 (2017): 218.

Kimball, Richard. "Muscular Mormonism." The International Journal of the History of Sport 25, no. 5 (2008): 549-578.

Koltko, M. E. (1991). The psychological foundations of the Mormon client in counseling and psycho-therapy. Journal of the Association of Mormon Counselors and Psychotherapists, 17(1), $1-26$.

Waugh, Thomas “Acting to Play Oneself: Performance in Documentary (1990). In The Documentary Film Reader : History, Theory, Criticism. Edited by Jonathan Kahana, New York: Oxford University Press, Incorporated, 2016. 815-828. 
“21. Selected Church Policies and Guidelines.”21.2.10. Accessed August 2019. https://www.churchofjesuschrist.org/study/manual/handbook-2-administering-thechurch/selected-church-policies-and-guidelines/selected-church-policies?lang=eng. 